1 Department of Health Policy, London School of Economics and Political Science, London, UK

2 Faculty of Public Health and Policy, London School of Hygiene and Tropical Medicine, London, UK

3 Department of Global Health Policy, Graduate School of Medicine, University of Tokyo, Tokyo, Japan

Correspondence to: K Shimizu k.shimizu1@lse.ac.uk Cite this as: BMJ 2020;370:m3221 http://dx.doi.org/10.1136/bmj.m3221 Published: 18 August 2020

\title{
Resurgence of covid-19 in Japan
}

\section{The government looks set to repeat its mistakes}

\section{Kazuki Shimizu, ${ }^{1,2}$ George Wharton, ${ }^{1}$ Haruka Sakamoto, ${ }^{3}$ Elias Mossialos ${ }^{1}$}

Japan has seen a resurgence of covid-19, and the effective reproduction number has been above 1 for two months. The daily confirmed cases reached nearly 2000 in early August. ${ }^{1}$

Since the start of the pandemic the country has focused on controlling clusters of more than five covid-19 cases and preventing environmental transmission in the " $3 \mathrm{Cs}$ ": closed spaces, crowded places, and close contact settings. ${ }^{2}$ Initially, early detection of clusters and investigation of linkages between clusters helped reduce the spread of infection. But it couldn't prevent the surge in incidence that began around mid-March. The declaration of a state of emergency in April helped control the pandemic's trajectory, ${ }^{3}$ although the measures lacked legal authority and depended on citizens' self-restraint. The state of emergency was lifted in late May.

Failings in the government's early handling of the crisis have exacerbated the pandemic's overall effect and resulted in 8.22 covid-19 deaths per million people: the third highest rate in the Western Pacific region after Philippines and Australia. ${ }^{1}$

\section{What went wrong}

Clear lessons have emerged from Japan's response to the first wave of covid-19. Firstly, Japan made insufficient effort to expand laboratory testing. ${ }^{2}$ Lack of capacity meant many requests for polymerase chain reaction (PCR) testing from doctors were rejected by the public health centres that govern community response to covid-19. This led to an increase in the number of undiagnosed cases, which in turn increased both community acquired and hospital acquired infections. ${ }^{4}$ Health system capacity was therefore diverted away from other essential health services.

Public health centres were overwhelmed by mid-March, as Japan relied on inefficient paper based systems for reporting patients' information. Use of manual data systems has resulted in inaccuracies and duplication of records.

Although citizens were asked to voluntarily avoid the $3 \mathrm{Cs},{ }^{2}$ behaviour modification campaigns were not effective in the early phase of the pandemic. As the Japanese authorities failed to introduce clear incentives to encourage public adherence, most people did not change their behaviour promptly. ${ }^{5}$ Closely linked to this, the government's communication strategy was inadequate, even during the state of emergency. Messages to avoid the $3 \mathrm{Cs}$ were clear, ${ }^{2}$ but the importance of physical distancing, washing hands frequently, staying home, and protecting health systems were not communicated persuasively enough to change behaviours.

Japan's response was also affected by tension between the politics and the science of the pandemic. An expert committee established as a subsidiary of the cabinet was insufficiently independent to provide truly impartial advice. The committee lacked representatives from essential disciplines such as economics, behavioural science, and communication, and decision making processes were poorly explained. For example, the committee's recommendation that social contact should decrease by $80 \%$ was later weakened by the government to "a minimum of $70 \%$, or ideally $80 \%$ " without further clarification.

Finally, the government lacked accountability and transparency. For example, the decision to postpone the Tokyo 2020 Olympics and Paralympics was made abruptly without explaining how the decision had been reached. ${ }^{7}$ Moreover, the prime minister undermined adherence to measures introduced under Japan's state of emergency by describing it as "different from a lockdown as we are seeing take place overseas." ${ }^{6}$ Visits to workplaces and public transport hubs initially decreased by only $23 \%$ and $46 \%$, respectively. ${ }^{8}$

The Japanese healthcare system was pushed to near collapse by inadequate human resources and personal protective equipment (PPE) in late April. ${ }^{2}$ Healthcare workers were blamed for the chaos, and many were bullied and harassed as a result. ${ }^{9}$

\section{Scrutiny, transparency}

Detailed scrutiny of the government's handling of the pandemic is essential to learn from earlier mistakes. Instead, however, the government abolished its expert committee in June, ${ }^{10}$ reducing scrutiny and transparency still further. Worse, as covid-19 surged in late July, Japan launched a domestic tourism campaign that encouraged people to travel freely throughout the country while failing to tackle the many public health problems that remained. ${ }^{11}$ The number of PCR tests is currently limited to fewer than 40000 a day, ${ }^{12}$ and the capacity of both hospitals and isolation facilities may be insufficient to cope with the resurgence. There has been scant discussion of how to expand testing, and digitalisation remains a work in progress.

Centrally coordinated command and control structures and unambiguous communication are vital to persuade the public to change its behaviour. Expanding testing capacity, implementing widespread testing for asymptomatic people, and effective contact tracing, isolation, and quarantine are also critical, along with fully digital epidemiology 
to monitor changes in the reproduction number and to inform an effective response. Logistics must be strengthened to allow faster and more responsive procurement of PPE, essential to protect frontline workers and patients.

Unless the Japanese government shifts from cluster based countermeasures to a response based on the above principles, examines and learns from previous mistakes, and deploys cutting edge science such as genetic sequencing and big data analytics, Japan's health services will be overwhelmed again and more lives will be needlessly lost in the months ahead.

Competing interests: We have read BMJ policy on declaration of interests and declare no conflicts of interest. KS receives research support from the Rotary Foundation, Japan Student Services Organisation, and British Council Japan Association.

Provenance and peer review: Commissioned; not externally peer reviewed.

1 European Centre for Disease Prevention and Control. COVID-19 situation update worldwide, as of 10 August 2020. https://www.ecdc.europa.eu/en/geographical-distribution-2019-ncov-cases

2 Hayasaki E. Covid-19: how Japan squandered its early jump on the pandemic. BMJ 2020;369:m1625. doi: 10.1136/bmj.m1625 pmid: 32332010

3 Looi MK. Covid-19: Japan ends state of emergency but warns of "new normal". BMJ 2020;369:m2100. doi: 10.1136/bmi.m2100 pmid: 32457055

4 Furuse $\mathrm{Y}$, Sando E, Tsuchiya N, etal. Clusters of coronavirus disease in communities, Japan, January-April 2020. Emerg Infect Dis 2020;26. doi: 10.3201/eid2609.202272. pmid: 32521222

5 Ministry of Health, Labour and Welfare, Japan. Results of national survey for COVID-19 countermeasures, 30 Apr 2020 [in Japanese]. https://www.mhlw.go.jp/st//newpage_11109.html

6 Press conference by the prime minister regarding the declaration of a state of emergency, $7 \mathrm{Apr}$ 2020. https://japan.kantei.go.jp/98_abe/statement/202004/_00001.html

7 Shimizu K, Devoid I. The 2020 Olympics and Paralympic Games and COVID-19. BMJ Opinion, 7 May 2020. https://blogs.bmj.com/bmigh/2020/05/07/the-2020-olympics-and-paralympic-gamescovid-19/

8 Google. Covid-19 community mobility reports, 17 Apr 2020. https://www.gstatic.com/covid19/mobility/2020-04-17_JP_Mobility_Report_en.pdf

9 Frontline health workers in Japan face discrimination over virus. Kyodo News 2020 May 29. https://english.kyodonews.net/news/2020/05/4a48fb130fd9-feature-frontline-health-workersin-japan-face-discrimination-over-virus.html

10 Cabinet Secretariat. The gist of minister's press conference [in Japanese]. 24 Jun 2020. https://corona.go.jp/news/pdf/daiijin_youshi_0624.pdf

11 Japan kicks off domestic tourism campaign as critics point to virus surge. Reuters July 2020 Jul 22. https://www.reuters.com/article/us-health-coronavirus-japan/confusion-swirls-as-japanlaunches-tourism-campaign-amid-virus-surge-idUSKCN24NOJE

12 Ministry of Health, Labour and Welfare, Japan. Open data. Number of PCR testing, 9Aug 2020. https://www.mhlw.go.jp/content/pcr_tested_daily.csy

This article is made freely available for use in accordance with BMI's website terms and conditions for the duration of the covid-19 pandemic or until otherwise determined by BMJ. You may use, download and print the article for any lawful, non-commercial purpose (including text and data mining) provided that all copyright notices and trade marks are retained. 